\title{
Tanshinone IIA inhibits human breast cancer cells through increased Bax to Bcl-xL ratios
}

\author{
CHIN-CHENG SU ${ }^{1,2}$ and YI-HSIANG LIN ${ }^{2}$ \\ ${ }^{1}$ Division of General Surgery, Buddhist Tzu Chi General Hospital, \\ Hualien 970, ${ }^{2}$ Tzu Chi University, Hualien 970, Taiwan, R.O.C
}

Received April 9, 2008; Accepted June 4, 2008

DOI: 10.3892/ijmm_00000030

\begin{abstract}
Tanshinone IIA $\left(\mathrm{C}_{19} \mathrm{H}_{18} \mathrm{O}_{3}\right)$ was extracted from danshen (Salviae miltiorrhizae radix). It has cytotoxic properties and induces apoptosis in many human cancer cells. The molecular mechanisms are poorly understood, therefore, in the present study, we aimed to elucidate its anticancer activity on human breast cancer MDA-MB-231 cells. The cytotoxic effects of tanshinone IIA on MDA-MB-231 cells were measured by MTT assay. The percentages of cells in different cell cycle phases were determined by flow cytometry. The protein expression of Bax and Bcl-2 was examined using Western blotting. The results showed that tanshinone IIA inhibits the proliferation of MDA-MB-231 cells in a dose- and time-dependent manner. Tanshinone IIA induces apoptosis in a dose-dependent manner and the percentage of cells in sub-G1 phase. It increases the protein expression of Bax but decreases the Bcl-2 expression in MDA-MB-231 cells. Our findings suggest that tanshinone IIA can inhibit the proliferation of MDA-MB-231 cells by active apoptosis. One of the mechanisms may be through upregulating the expression of Bax but down-regulating Bcl-2 expression and then inducing apoptosis. In conclusion, tanshinone IIA has therapeutic potential in breast cancer patients.
\end{abstract}

\section{Introduction}

Danshen first appeared in the Shennong Bencao Jing (ca. 100 A.D.) and was widely used in ancient Chinese medicine (1). Tanshinone IIA is derived from danshen (Salviae miltiorrhizae radix) and was first described by researchers in 1968. It is known to have anticancer, (2) antioxidant, (3) and anti-

Correspondence to: Dr Chin-Cheng Su, Division of General Surgery, Buddhist Tzu Chi General Hospital, No. 707, Sec. 3, Chung Yang Road, Hualien 970, Taiwan, R.O.C

E-mail: succ.maeva@msa.hinet.net

Key words: tanshinone IIA, Bax, Bcl-2, breast cancer inflammatory properties (4). It is well documented that tanshinone IIA can induce apoptosis in some human cancer cells, such as leukemia, (5) human hepatocellular carcinoma, (6) and nasopharyngeal carcinoma cells (7). The anticancer activity of tanshinone IIA on the human breast cancer cell in vitro and in vivo is also documented (8). However, the molecular mechanisms are not yet elucidated. In the present study, we evaluated the effects and molecular mechanisms of Tanshinone IIA on MDA-MB-231 cells.

\section{Materials and methods}

Chemicals and reagents. Tanshinone IIA was purchased from Herbasin Co. (Shenyang, China). Aprotinin, antipain, sodium deoxycholate, leupeptin, propidium iodide (PI), sodium orthovanadate, Triton X-100, Tris- $\mathrm{HCl}$, ribonuclease-A and MTT[3-(4,5)-dimethylthiahiazo (-z-y1)-3,5-diphenytetrazoliumromide] were obtained from Sigma Chemical Co. (St. Louis, MO, USA). Dimethyl sulfoxide (DMSO), potassium phosphates and TE buffer were purchased from Merck Co. (Darmstadt, Germany). L-15 medium, fetal bovine serum (FBS), penicillin-streptomycin, trypsin-EDTA, and glutamine were obtained from Gibco BRL (Grand Island, NY, USA).

Human breast cancer cell line (MDA-MB-231). The human breast cancer cell line MDA-MB-231 was obtained from the Food Industry Research and Development Institute (Hsinchu, Taiwan). The cells were placed into $75-\mathrm{cm}^{3}$ tissue culture flasks and grown at $37^{\circ} \mathrm{C}$ in a humidified atmosphere $\left(\mathrm{CO}_{2}\right.$ was not present), in an L-15 medium (Sigma), containing $10 \%$ heat-inactivated FBS, $1 \%$ penicillin-streptomycin $(10,000 \mathrm{U} /$ $\mathrm{ml}$ penicillin and $10 \mathrm{mg} / \mathrm{ml}$ streptomycin). The data presented in this report are from a minimum of three independent experiments.

Effects of tanshinone IIA on the viability of MDA-MB-231 cells. The MDA-MB-231 cells were plated in a density of $1 \times 10^{5}$ cells/well and grown for $24 \mathrm{~h}$. Various concentrations of tanshinone IIA were added and cells were grown for 24, 48 and $72 \mathrm{~h}$. Only DMSO $0.2 \%$ (solvent) was added to the control regimen to determine cell viability. After 24, 48 and $72 \mathrm{~h}$ of culture, the viability was evaluated by MTT assay (9) in triplicate. Briefly, MDA-MB-231 cells were seeded in a 6-well plate at a density of $1 \times 10^{5}$ cells/well and allowed to adhere overnight. After removing the medium, $2000 \mu \mathrm{l}$ of 
DMSO

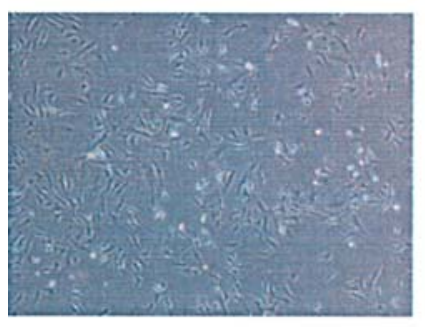

$10 \mu \mathrm{g} / \mathrm{ml}$

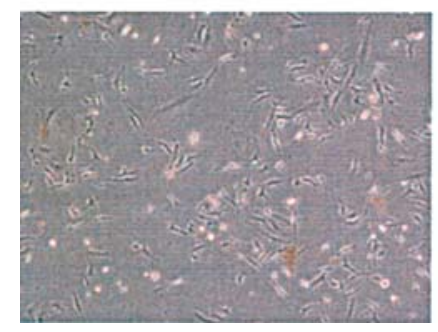

$1 \mu \mathrm{g} / \mathrm{ml}$

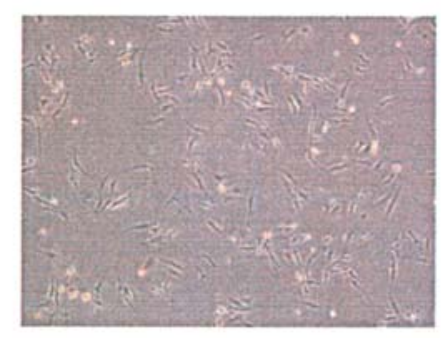

$20 \mu \mathrm{g} / \mathrm{ml}$

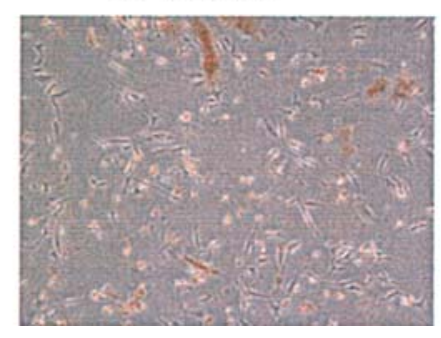

$3 \mu \mathrm{g} / \mathrm{ml}$

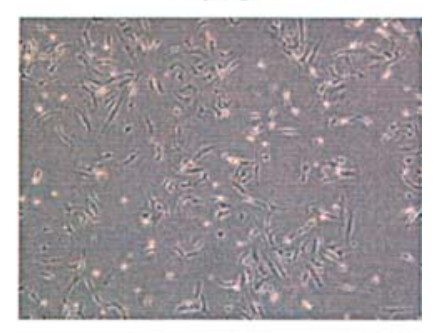

$30 \mu \mathrm{g} / \mathrm{ml}$

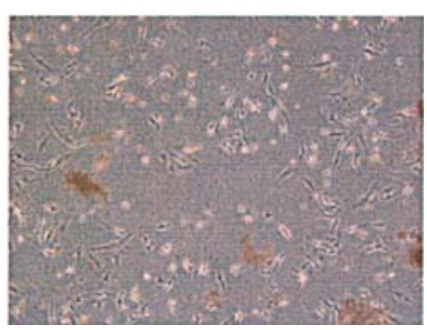

Figure 1. MDA-MB-231 cells were treated with various concentrations of Tan IIA for $24 \mathrm{~h}$. Cells were examined using a contrast-phase microscope (magnification $\mathrm{x} 50$ ) and photographed.

DMSO

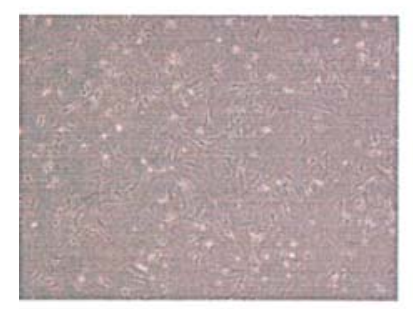

$10 \mu \mathrm{g} / \mathrm{ml}$

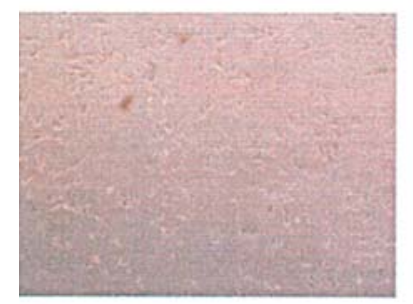

$1 \mu \mathrm{g} / \mathrm{ml}$

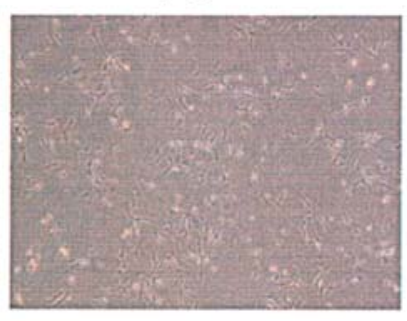

$20 \mu \mathrm{g} / \mathrm{ml}$

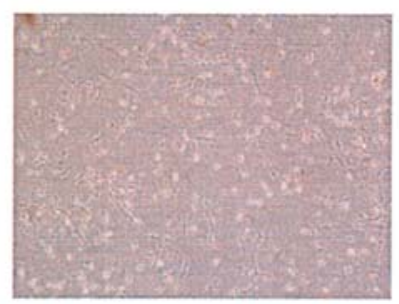

$3 \mu \mathrm{g} / \mathrm{ml}$

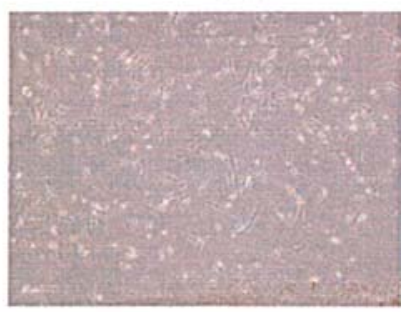

$30 \mu \mathrm{g} / \mathrm{ml}$

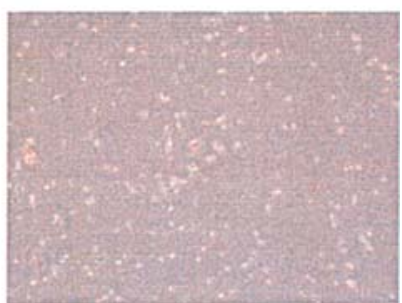

Figure 2. MDA-MB-231 cells were treated with various concentrations of Tan IIA for 48 h. Cells were examined using a contrast-phase microscope (magnification $\mathrm{x} 50$ ) and photographed.

fresh medium per well, containing $10 \mathrm{mM}$ HEPES was then added, $200 \mu 1$ of 3-(4,5-dimethylthiazol-2-yl)-2,5-diphenyl$2 \mathrm{H}$-tetrazolium bromide (MTT) was added to the wells and the plate was incubated for $30 \mathrm{~min}$ at $37^{\circ} \mathrm{C}$ in dark conditions. The medium was removed and $1000 \mu \mathrm{l}$ DMSO was added to the wells. Absorbance was measured using an ELISA plate reader at $590 \mathrm{~nm}$.

Cell cycle analysis for MDA-MB-231 cells treated with tanshinone IIA using a flow cytometry assay. The percentage of cells in sub-G1, G0/G1, S and G2/M phases was determined by flow cytometry as described (10). Briefly, $1 \times 10^{6}$ MDAMB-231 cells/10-cm dishes were incubated with tanshinone IIA at 0,6 and $12 \mu \mathrm{g} / \mathrm{ml}$ concentrations for $48 \mathrm{~h}$ and at 0 , 1.25 and $2.5 \mu \mathrm{g} / \mathrm{ml}$ concentrations for $72 \mathrm{~h}$ before the cells were harvested by centrifugation. The cells, after being harvested were washed with PBS, then fixed gently (drop by drop) in $70 \%$ ethanol (in PBS), in ice, overnight. They were then resuspended in PBS containing $40 \mu \mathrm{g} / \mathrm{ml} \mathrm{PI,} 0.1 \mathrm{mg} / \mathrm{ml}$ RNase (Sigma) and $0.1 \%$ Triton $\mathrm{X}-100$. After $30 \mathrm{~min}$ at $37^{\circ} \mathrm{C}$ 
MDA MB-231 cells were treated with Tan IIA for 24, 48, 72hrs.

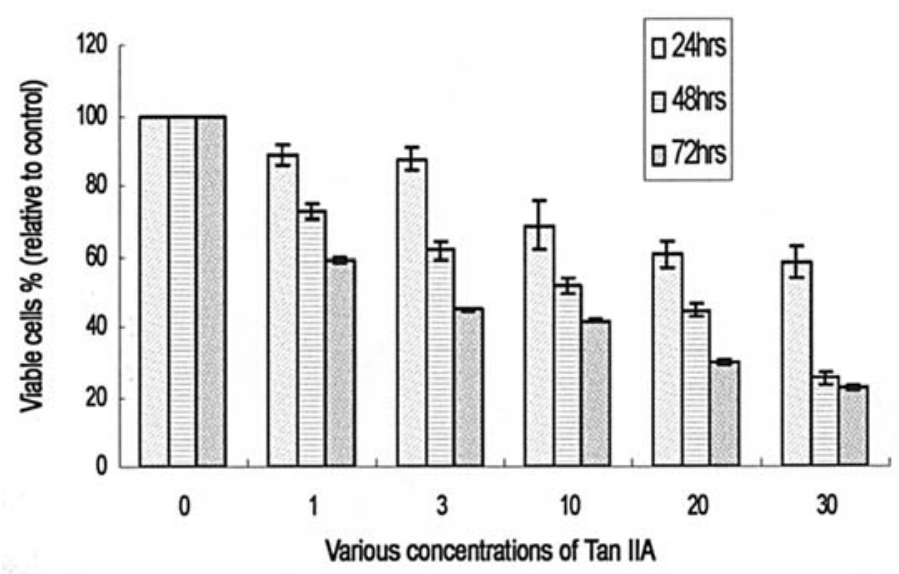

Figure 3. The MDA-MB-231 cells were plated at a density of $1 \times 10^{5}$ cells/ well and grown for $24 \mathrm{~h}$. The various concentrations of tanshinone IIA were added and cells grown for 24,48 , and $72 \mathrm{~h}$, while only DMSO $0.2 \%$ (solvent) was added to the control regimen. After 24,48 and $72 \mathrm{~h}$ of culture, the viability was evaluated by MTT assay in triplicate.

in dark conditions, the cells were analyzed using flow cytometry (Becton-Dickinson, San Jose, CA, USA) and equipped with an argon laser at $488 \mathrm{~nm}$. Cell cycle and apoptosis were then determined and analyzed using the ModFit software. The average of the percentage of each phase in the cell cycle was representative of the three independent experiments.

Protein preparation. Approximately $1 \times 10^{6}$ cells $/ 10-\mathrm{cm}$ dish were incubated with tanshinone IIA at 0,6 and $12 \mu \mathrm{g} / \mathrm{ml}$ concentrations for $48 \mathrm{~h}$ before the cells were harvested by centrifugation. Protein was extracted as described (11). Briefly, cell pellets were resuspended in modified RIPA buffer $(50 \mathrm{mM}$ Tris- $\mathrm{HCl}, \mathrm{pH} 7.5,150 \mathrm{mM} \mathrm{NaCl}, 1 \%$ Nonidet p-40, $0.25 \%$ sodium deoxycholate, $1 \mathrm{mM}$ EGTA, $1 \mathrm{mM}$ DTT, $1 \mathrm{mM}$ PMSF, $1 \mathrm{mM}$ sodium orthovanadate, $1 \mathrm{mM}$ sodium fluoride, $5 \mu \mathrm{g} / \mathrm{ml}$ aprotinin, $5 \mu \mathrm{g} / \mathrm{ml}$ leupeptin and $5 \mu \mathrm{g} / \mathrm{ml}$ antipain) for $30 \mathrm{~min}$ at $4^{\circ} \mathrm{C}$. Lysates were immediately centrifuged at $13,000 \mathrm{x} \mathrm{g}$ for $20 \mathrm{~min}$ at $4^{\circ} \mathrm{C}$ and supernatant was collected, aliquoated $(50 \mu \mathrm{g} /$ tube $)$ and stored at $-80^{\circ} \mathrm{C}$ before being assayed. The protein concentrations were measured using the Bradford method (12).

Western blotting for examining the effect of tanshinone IIA on the expression of Bax, Bcl-xL, p21, caspase- 8 and $\beta$-actin in $M D A-M B-231$ cells. All samples were separated by sodium dodecylsulfate polyacrylamide (SDS-PAGE) gel electrophoresis (10 and 13\%) (Bio-Rad Life Science Products, Hercules, CA, USA) as described (11). The SDSseparated proteins were followed by equilibration in transfer buffer [50 mM Tris, pH 9.0, $40 \mathrm{mM}$ glycine, $0.375 \%$ SDS, $20 \%$ methanol and electro-transferred to Immobilon-P Transfer Membrane (Millipore Corporation, Bedford, MA, USA)]. Then the blot was blocked with a solution containing $5 \%$ non-fat dry milk in Tris-buffered saline (10 mM Tris,
$150 \mathrm{mM} \mathrm{NaCl}$ (Sigma Chemical Co.), contained in $0.05 \%$ Tween-20 for $1 \mathrm{~h}$. It was then washed and incubated with antibodies to Bax, Bcl-xL, p21, caspase-8 and B-actin, (Upstate, Lake Placid, NY, USA) at $4^{\circ} \mathrm{C}$ overnight. After incubating with anti-mouse peroxidase-conjugated antibody (Santa Cruz, CA, USA), the signal was visualized by enhanced chemiluminescence (ECL, Amersham Pharmacia Biotech). The detection of $\beta$-actin was used as an internal control in all of the data for Western blotting.

Statistical analysis. Values are presented as a mean \pm SD. Student's t-test was used to analyze the statistical significance and $\mathrm{p}<0.05$ was considered significant for all tests.

\section{Results}

Morphological changes of human breast cancer MDA-MB231 cells in response to various concentrations of tanshinone IIA. The MDA-MB-231 cells were treated with various concentrations $(0,1,3,10,20$ and $30 \mu \mathrm{g} / \mathrm{ml})$ of tanshinone IIA for 24 and 48 h (Figs. 1 and 2). Cells were examined using contrast-phase microscope $(x 50)$ and photographed. The results indicated that the number of viable cells decreased as the concentration increased, suggesting that tanshinone IIA induced cell death on MDA-MB-231 cells.

The effects of tanshinone IIA on the viability of MDA-MB231 cells. The MDA-MB-231 cells $\left(1 \times 10^{5}\right.$ cells/well) were plated in L-15 medium $+10 \%$ FBS with various concentrations $(0,1,3,10,20$ and $30 \mu \mathrm{g} / \mathrm{ml})$ of tanshinone IIA for 24,48 and $72 \mathrm{~h}$. The cells were collected by centrifugation and the viable cells were determined by MTT assay as previously described. The viable cell percentages relative to control were $88.58 \pm 2.85,87.54 \pm 3.10,68.70 \pm 7.06$, $60.23 \pm 3.50$ and $58.23 \pm 4.11 \%$, respectively, when cultured with various concentrations of tanshinone IIA $(1,3,10,20$ and $30 \mu \mathrm{g} / \mathrm{ml}$ ) for $24 \mathrm{~h}$. The viable cell percentages relative to control were $72.72 \pm 2.50,61.48 \pm 2.47,51.56 \pm 1.94$, $44.53 \pm 1.69$ and $25.15 \pm 1.82 \%$, respectively, when cultured with various concentrations of tanshinone IIA $(1,3,10,20$ and $30 \mu \mathrm{g} / \mathrm{ml}$ ) for $48 \mathrm{~h}$. The viable cell percentages relative to control were $59.14 \pm 0.75,44.77 \pm 0.29,41.65 \pm 0.34$, $29.84 \pm 0.66$, and $22.61 \pm 0.77 \%$, respectively, when cultured with various concentrations of tanshinone IIA $(1,3,10$ and 20 and $30 \mu \mathrm{g} / \mathrm{ml}$ ) for $72 \mathrm{~h}$ (Fig. 3). The $\mathrm{IC}_{50}$ were 34.14 \pm 4.55 , $11.85 \pm 0.29$ and $2.40 \pm 0.02 \mu \mathrm{g} / \mathrm{ml}$ respectively, when MDAMB-231cells were treated with tanshinone IIA for different durations (24, 48 and $72 \mathrm{~h})$. The proliferation of colo 205 was obviously inhibited by tanshinone IIA in a dose- and time-dependent manner.

Tanshinone IIA induced apoptosis in MDA-MB-231 cells. The results of FCM showed that the percentages of sub-G1 were 4.32, 9.93 and $11.8 \%$, respectively, when MDA-MB231 cells were cultured with various concentrations (control, 6 and $12 \mu \mathrm{g} / \mathrm{ml}$ ) of tanshinone IIA for $48 \mathrm{~h}$ (Fig. 4). The percentages of sub-G1 were 5, 8.92 and $9.26 \%$, respectively, when MDA-MB-231 cells were cultured with various concentrations (control, 1.25 and $2.5 \mu \mathrm{g} / \mathrm{ml}$ ) of tanshinone IIA for 72 h (Fig. 5). 


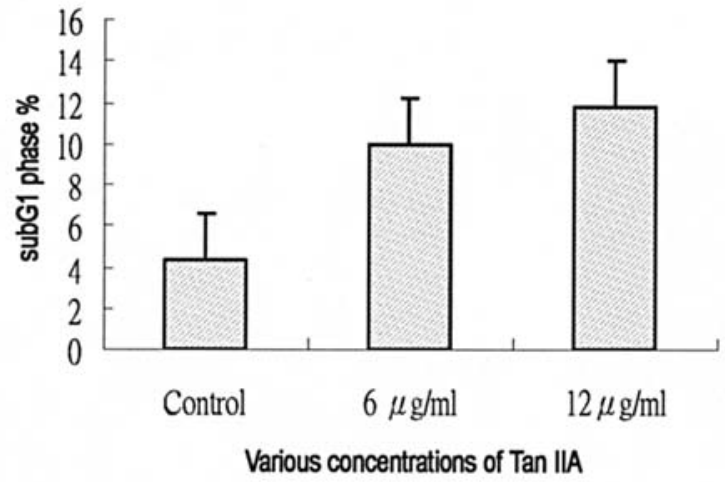

Figure 4. MDA-MB 231 cells were treated with Tan IIA for $48 \mathrm{~h}$. Then the sub-G1 cell cycle percentage was evaluated by FACS.

A

Bax

$\beta$-actin

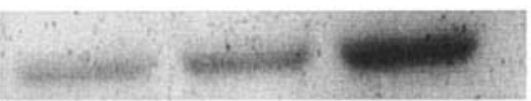

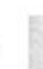
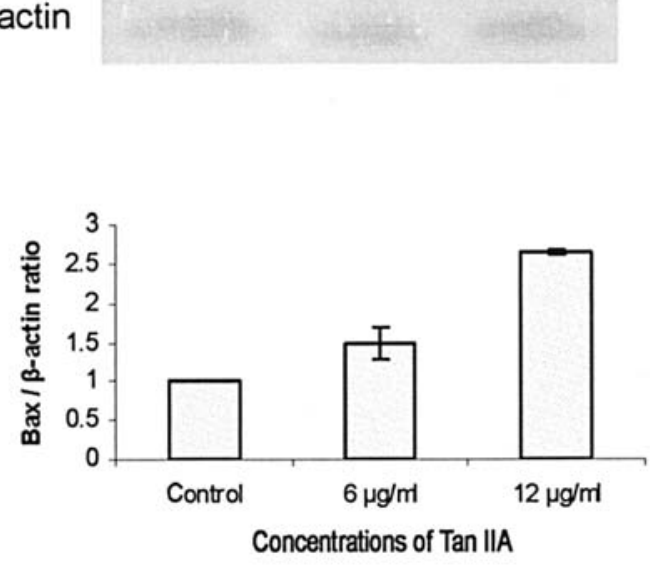

C

\section{Caspase 8}

$\beta$-actin

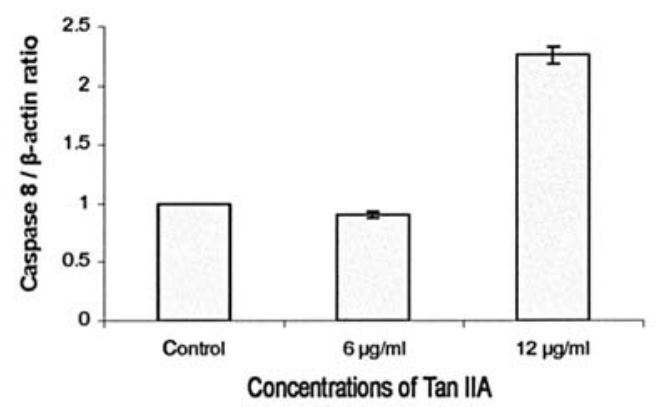

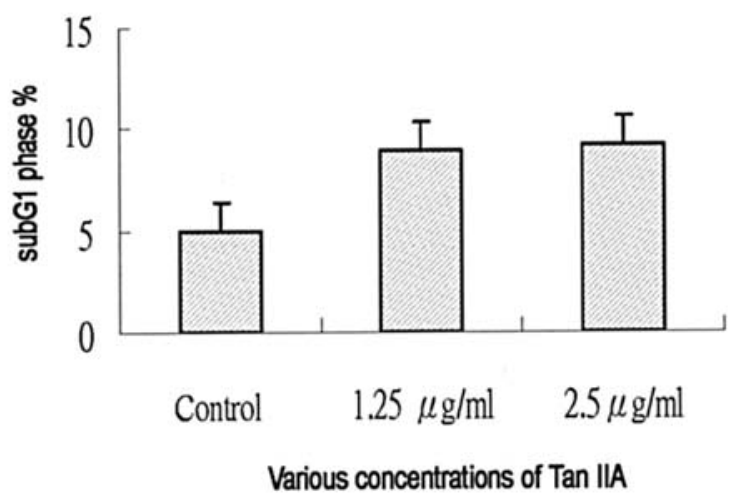

Figure 5. MDA-MB 231 cells were treated with Tan IIA for $72 \mathrm{~h}$. Then the sub-G1 cell cycle percentage was evaluated by FACS.

B

p21

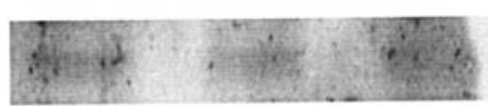

$\beta$-actin

MDAMB-231 cells were treated with Tan IIA for $48 \mathrm{hrs}$.

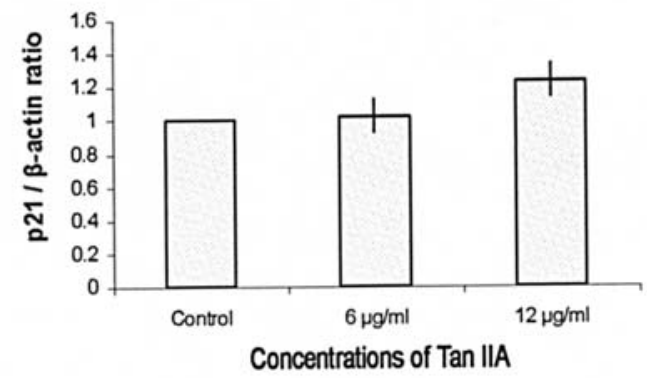

D

$\mathrm{Bcl}-\mathrm{xL}$

$\beta$-actin

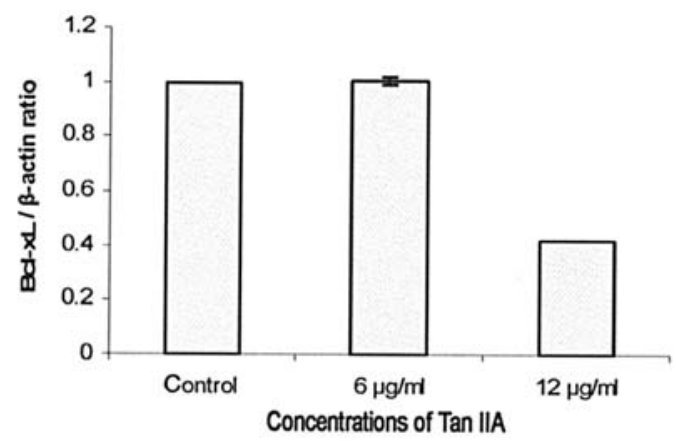

Figure 6. The protein expression of Bax, Bcl-xL, p21, caspase-8 and B-actin in MDA-MB-231 cells treated with tanshinone IIA (Tan) for 48 h. Tan increased Bax to Bcl-xL ratios and up-regulated the protein expression of $\mathrm{p} 21$ and caspase- 8 in vitro. 
Western blot analysis on the effect of tanshinone IIA on Bax, Bcl-xL, p21, caspase-8 and $\beta$-actin in MDA-MB-231 cells. MDA-MB-231 cells were harvested in the presence of tanshinone IIA for Western blotting and the results indicated that tanshinone IIA increased the expression of Bax, p21 and caspase-8 (Fig. 6c). Tanshinone IIA decreased the protein expression of Bcl-xL (Fig. 6d).

\section{Discussion}

The present study showed that the proliferation of MDAMB-231 cells was inhibited by tanshinone IIA in a dose- and time-dependent manner. This finding is in agreement with others, demonstrating that tanshinone IIA induces cytotoxicity in MDA-MB-231 cells and induces apoptosis in human breast cancer MDA-MB-231 cells (8). It is welldocumented that an increased Bax and decreased Bcl-xL protein expression will induce cancer cell apoptosis (13-15). Although many experiments have demonstrated that tanshinone IIA induces apoptosis in other cancer cell lines $(8,16)$, this is the first study showing that tanshinone IIA inhibits the proliferation of human breast cancer cells through inducing apoptosis by increasing Bax to Bcl-xL ratios in vitro. Our results also show that tanshinone IIA increases the protein levels of p21 and caspase- 8 in human breast cancer MDA-MB-231 cells. It is well documented that p21 (WAF1 and Cip-1) has the potential to induce G1 arrest $(17)$ and apoptosis $(18,19)$. One of the mechanisms by which tanshinone IIA induces apoptosis in human breast cancer MDA-MB-231 cells may be through the up-regulation of expression of $\mathrm{p} 21$, inducing apoptosis. Another mechanism may be through the membrane receptor pathway. Taken together, these data suggest that tanshinone IIA has significant therapeutic potential for human breast cancer.

\section{Acknowledgements}

This study was supported by the grant TCRD96-10 from the Research Section of the Buddhist Tzu Chi General Hospital, Hualien, Taiwan, R.O.C. This study was partially supported by The Chen-Han Foundation for Education.

\section{References}

1. Li ZT, Yang BJ and Ma GE: Chemical studies of Salvia miltiorrhiza f.alba. Yaoxue Xuebao 26: 209-213, 1991.

2. Wu WL, Chang WL and Chen CF: Cytotoxic activities of tanshinone against human carcinoma cell lines. Am J Chin Med 19: 207-216, 1991

3. Lin TJ: Antioxidation mechanism of schizandrin and tanshinonatic acid A and their effects on the protection of cardio-toxic action of adriamycin. Shengli Kexue Jinzhan 22: 342-345, 1991.
4. Liang Y, Yang YM and Yuan SL: Studies on Pharmic mechanism and clinic application of Tanshinone. Traditional Herbal Drugs 31: 304-306, 2000.

5. Sung HJ, Choi SM, Yoon Y and An KS: Tanshinone IIA, an ingredient of Salvia miltiorrhiza BUNGE, induces apoptosis in human leukemia cell lines through the activation of caspase-3. Exp Mol Med 31: 174-178, 1999.

6. Yuan SL, Wei YQ, Wang XJ, Xiao F, Li SF and Zhang J: Growth inhibition and apoptosis induction of tanshinone II-A on human hepatocellular carcinoma cells. World J Gastroenterol 10: 2024-2028, 2004.

7. Yuan S, Wang Y, Chen X, Song Y and Yang Y: A study on apoptosis of nasopharyngeal carcinoma cell line induced by Tanshinone II A and its molecular mechanism. Huaxi Yike Daxue Xuebao 33: 84-86, 2002.

8. Wang X, Wei Y, Yuan S, Liu G, Lu Y, Zhang J and Wang W: Potential anticancer activity of tanshinone IIA against human breast cancer. Int J Cancer 116: 799-807, 2005.

9. Mossman T: Rapid colorimetric assay for cellular growth and survival: application to proliferation and cytotoxicity assays. J Immunol Methods 65: 55-63, 1983.

10. Li TM, Chen GW, Su CC, Lin JG, Yeh CC, Cheng KC and Chung JG: Ellagic acid induced p53/p21 expression, G1 arrest and apoptosis in human bladder cancer T24 cells. Anticancer Res 25: 971-979, 2005.

11. Chen HC, Hsieh WT, Chang WC and Chung JG: Aloe-emodin induced in vitro $\mathrm{G} 2 / \mathrm{M}$ arrest of cell cycle in human promyelocytic leukemia HL-60 cells. Food Chem Toxicol 42: 1251-1257, 2004.

12. Bradford MM: A rapid and sensitive method for the quantization of microgram quantities of protein using the principle of protein-dye binding. Anal Biochem 72: 248-254, 1976.

13. Adams JM and Cory S: The Bcl-2 protein family: arbiters of cell survival. Science 281: 1322-1326, 1998.

14. Nomura M, Shimizu S, Ito T, Narita M, Matsuda H and Tsujimoto Y: Apoptotic cytosol facilitates Bax translocation to mitochondria that involves cytosolic factor regulated by Bcl-2. Cancer Res 59: 5542-5548, 1999.

15. Murphy KM, Ranganathan V, Farnsworth ML, Kavallaris M and Lock RB: Bcl-2 inhibits Bax translocation from cytosol to mitochondria during drug-induced apoptosis of human tumor cells. Cell Death Differ 7: 102-111, 2000.

16. Hu H, Zhang Y, Huang F and Deng H: Inhibition of proliferation and induction of apoptosis by tanshinone II A in NCIH460 cell. Zhong Yao Cai 28: 301-304, 2005.

17. Deng C, Zhang P, Harper JW, Elledge SJ and Leder P: Mice lacking $\mathrm{p} 21^{\mathrm{CIP} 1 / \mathrm{WAF} 1}$ undergo normal development, but are defective in G1 checkpoint control. Cell 82: 675-684, 1995.

18. Lowe SW, Schmitt EM, Smith SW, Osborne BA and Jacks T: p53 is required for radiation induced apoptosis in mouse thymocytes. Nature 362: 847-849, 1993.

19. Yonish-Rouach E, Resnitzky D, Lotem J, Sachs L, Kimchi A and Oren M: Wild-type p53 induces apoptosis of myeloid leukaemic cells that is inhibited by interleukin-6. Nature 352 : 345-347, 1991. 